\title{
WOOD MANUFACTURING AND FURNITURE INDUSTRY IN LITHUANIA
}

\author{
Lilija Kaledienè \\ Vilnius University, Lithuania \\ Ernesta Lubyte \\ Vilnius Gediminas Technical University, Lithuania \\ Vilmante Karlavičienè, \\ Linnaeus University, Sweeden
}

\begin{abstract}
Wood manufacturing and furniture industry is a very old and traditional industry in Lithuania. This is because the processing of wood in Lithuania are favorable conditions, nearly a third of Lithuania's territory is covered with forests. In 2009, the state owned 1065 thousand ha or $49 \%$ of the forests. The other part consists of private forests and woodlands intended for privatization (restitution). In early 2010, 2815 companies of various sizes were engaged in manufacturing of wood products. The number of companies has slightly decreased recently, their specializations have undergone changes. Export of Lithuanian wood products was increasing for a number of years and reached EUR 1.4 billion in 2007. Import experienced similar growth and reached EUR 900 million in the same year. The share of wood products in the whole export in 2007 accounted for $11.9 \%$, in 2009 it dropped down to $10.3 \%$. Wood processing industry, product manufacturing process creates a lot of waste. Some are harmless, others - hazardous, the latter must be given special attention., the wood products industry and its manufacturing processes at the beginning of 2009 were raised to 42,797 tons of various industrial wood wastes. 2009 year-end balance of wood industry waste was 43,089 tones. Hazardous waste in early 2009 was 285 tons, and at the end of the year - 2,532 tons.
\end{abstract}

\section{KEYWORDS}

Wood manufacturing, furniture industry, forestry, paper industry, wood export, wood waste, hazardous waste.

\section{INTRODUCTION}

Wood manufacturing and furniture industry is a very old and traditional industry in Lithuania. This is because the processing of wood in Lithuania are favorable conditions, nearly a third of Lithuania's territory is covered with forests. In Lithuania forests occupy about 2 million hectares, it consists $31.1 \%$ of total land area. Forest resources are scattered and dispersed all over the country - least wooded regions in the west, and dense forests, especially coniferous trees, forested areas are east of the country. Central Lithuania is part of larger mixed forest. Lithuanian sector of forest economy (cluster) consists of companies engaged in forestry and three main branches of the industry (wood, paper and furniture). In 2010, there were 2815 wood manufacturing and furniture companies in Lithuania. Of these, 1929 companies - wood processing sub-branches, 794 - furniture industry, and 92 - paper industry. Wood furniture and expressions dominated by small, up to 50 employees within the company. This is particularly true of furniture and paper manufacturing businesses. 
Lithuania dominated by traditional industries, focused on materials processing, and the countries' rapid economic expansion, which increases the value added and exports. As Lithuania's high-tech industrial value added in the last five years is only about $2.5 \%$ of the total value created by the successful economic growth necessary to implement the new world emerging technologies and innovative solutions to all branches of the economy. A large part of the farm economy accounts for the forest sector's role is important, therefore, necessary to analyze the sector's further development and competitiveness of potential [3].

Before 2004, most companies relied upon cheap labor force and little invested into production technologies. The situation fundamentally changed after Lithuania accessing the EU followed by the rising cost of labor force. Industries turned to investing into new technologies, and this process is still continuing. They constantly look for new production methods, more advanced technologies and take efforts to assure production quality, as this is the only way for them to extend their markets [8].

In order to describe wood manufacturing and furniture industry, the quantities of waste and pollution, it is necessary to analyze the timber industry works and issues.

\section{FOREST AND RAW WOOD MARKET}

Lithuanian forestry sector has its own raw resources and sufficiently balanced round wood market, therefore it is capable of further development of wood industry and its products export. Forest areas and their resources are further growing.

Table 1. Lithuanian forests

\begin{tabular}{|l|c|c|c|}
\hline Indicators & $\mathbf{2 0 0 7}$ & $\mathbf{2 0 0 8}$ & $\mathbf{2 0 0 9}$ \\
\hline Woodland, thousand ha & 2030 & 2040 & 2045 \\
\hline Forest land percentage, \% & 32,7 & 32,8 & 32,9 \\
\hline Total wood volume, million $\mathrm{m}^{3}$ & 405 & 422 & 427 \\
\hline Average wood volume per 1 ha, $\mathrm{m}^{3}$ & 199 & 207 & 209 \\
\hline${\text { Wood growth in meters, million } \mathrm{m}^{3}}^{\text {Wood felling, million } \mathrm{m}^{3}}$ & 13,1 & 13,6 & 13,8 \\
\hline Wood $^{3}$ & 6,4 & 5,8 & 5,6 \\
\hline
\end{tabular}

Structural dynamics of forest stands is also good far: the share of mature timber coniferous (pine and fir) forest stands is growing. Today, coniferous forest stands occupy $56 \%$ of the total woodland. The size of felling still allows stock accumulation, planning their further increasing use. In 2009, the state owned 1065 thousand ha or $49 \%$ of the forests. The other part consists of private forests and woodlands intended for privatization (restitution). Rather protracted process of privatization (restitution of former owners) results in insufficient use of the forest reserve intended for this purpose (13\% of the total woodland). Another unfavorable factor is 240 thousand owners of private forests, which results in too small size of one estate. In 2009, very significant part (36\%) of private forests consisted of under 1 ha estates, $33.2 \%$ 1-3 ha, $13.6 \%$ - 3-5, and estates of over 5 ha area accounted for as little as $17.2 \%$. At the same time, some process of private estate concentration has already started. 

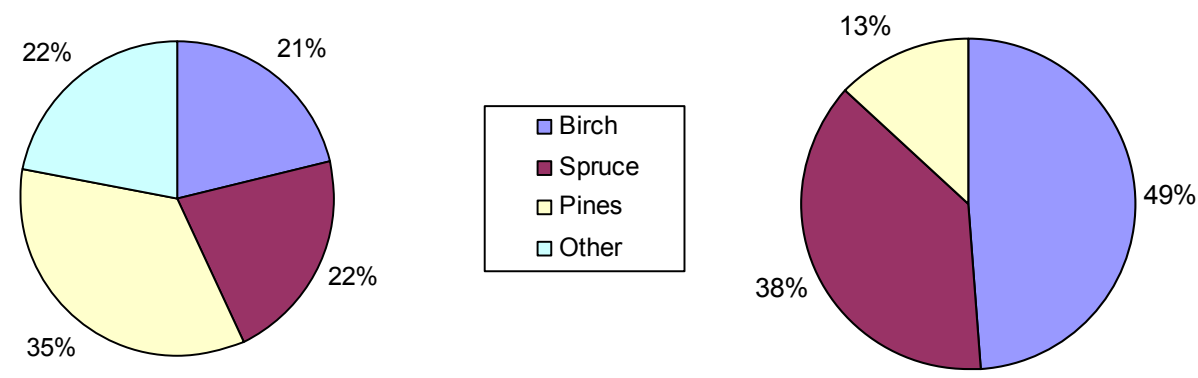

$\square$ State

$\square$ Spruce

$\square$ Pines

$\square$ Other

Figure 1. Stand distribution and forest property.

Round wood supply has been very close to its demand for a number of years: it was sufficiently balanced. Besides, a trend of decreasing demand for raw wood was observed. No thorough information about the supply and use of raw wood in 2009 is available. To the best knowledge available, in 2009 the state forest enterprises produced and sold the same amount of round wood as in previous years, i.e. 3.2 million $\mathrm{m}^{3}\left(2007-3.16\right.$ million $\mathrm{m}^{3}, 2008-3.15$ million $\mathrm{m}^{3}$ ) and the volume of its products produced and sold by private forest sector has underwent very minor decrease.

Table 3. Round wood supply, $1000 \mathrm{~m}^{3}$

\begin{tabular}{|l|c|c|c|c|}
\hline Rates & $\mathbf{2 0 0 4}$ & $\mathbf{2 0 0 5}$ & $\mathbf{2 0 0 6}$ & $\mathbf{2 0 0 7}$ \\
\hline Produced & 6112 & 6286 & 6042 & 6410 \\
\hline Imported & 224 & 289 & 208 & 397 \\
\hline Consumed & 5030 & 4893 & 5324 & 5013 \\
\hline Exported & 1220 & 1175 & 1147 & 1713 \\
\hline Consumed: & 3156 & 3193 & 2913 & 2905 \\
\hline For wood production & 1874 & 1700 & 2411 & 2108 \\
\hline Other consumption
\end{tabular}

Use of wood for fuel is increasing. Industrial boiler houses supplying heating increased the use of wood in heat production in 1992 - 1993. In the beginning, this activity was rather slow, but in 2009 as many as 360 boiler houses using biofuel were operating in Lithuania, increasing volumes of heat are produced from wood and other biological materials.

Table 4. Wood fuel, ths. $m^{3}$

\begin{tabular}{|l|c|c|c|c|}
\hline & $\mathbf{2 0 0 5}$ & $\mathbf{2 0 0 6}$ & $\mathbf{2 0 0 7}$ & $\mathbf{2 0 0 8}$ \\
\hline Produced & 3674 & 3860 & 3718 & 3866 \\
\hline Consumed, in total & 3616 & 3715 & 3602 & 3750 \\
\hline Including household consumption & 2207 & 2201 & 2046 & 2053 \\
\hline
\end{tabular}

Biomass share in the boiler houses supplying central heating accounts for $18 \%$ of the total fuel used and in the nearest future, it should rise up to $50 \%$ because of growing gas prices. 
First of all, use of forest felling waste, followed by other wood should increase. Expected growing demand for wood fuel can activate the entire round wood market and result in the rising of prices in the nearest future.

\section{WOOD RAW MATERIAL PROBLEMS}

As never before, in 2010 was refreshes the local forest management and wood utilization problems. Much debate has caused Independent Market Institute offer to privatize state forests, state control of national forests and performance audit of the Government initiative to investigate further as it is now more efficient use of state assets and concluded that the forest produces too little income. Again, it recalled that economic activity has for many years, not at all used the so-called stand, still not returned to future owners of the forest, that too much wood is exported, the domestic market continued to feel the lack of it [2]

Table 5. Round wood balances, million $\mathrm{m}^{3}$.

\begin{tabular}{|l|c|c|c|c|}
\hline Year & Produced & Imported & Exported & Used \\
\hline 2006 & 6,04 & 0,21 & 1,15 & 5,33 \\
\hline 2007 & 6,41 & 0,40 & 1,71 & 5,01 \\
\hline 2008 & 5,79 & 0,24 & 1,23 & 4,66 \\
\hline 2009 & 5,68 & 0,21 & 0,78 & 5,27 \\
\hline
\end{tabular}

Table 6. Used round wood, thousand $m^{3}$.

\begin{tabular}{|l|c|c|c|c|}
\hline & $\mathbf{2 0 0 6}$ & $\mathbf{2 0 0 7}$ & $\mathbf{2 0 0 8}$ & $\mathbf{2 0 0 9}$ \\
\hline Timber industry & 2912 & 2923 & 2494 & 2499 \\
\hline Construction industry & 79 & 75 & 59 & 38 \\
\hline Forestry & 81 & 114 & 83 & 80 \\
\hline Other users & 2254 & 1900 & 2022 & 2658 \\
\hline \multicolumn{2}{r|r|}{} \\
\hline
\end{tabular}

It should be noted that the use of round wood statistics show that the local market is still balanced enough that the industrial use of round wood does not, yet that there is sufficient internal resources to increase its supply.

\section{PRODUCTION OF WOOD PRODUCTS}

In early 2010, 2815 companies of various sizes were engaged in manufacturing of wood products. The number of companies has slightly decreased recently, their specializations have undergone changes. It was noticed that quite a lot of companies changed their profile and started manufacturing furniture and its components. 
Table 7. Number of operating companies.

\begin{tabular}{|c|c|c|c|c|c|}
\hline & 2006 & 2007 & 2008 & 2009 & 2010 \\
\hline Forestry & 778 & 769 & 766 & 723 & 655 \\
\hline Timber industry & 1560 & 1489 & 1434 & 1376 & 1274 \\
\hline Paper industry & 112 & 106 & 96 & 95 & 92 \\
\hline Furniture industry & 611 & 653 & 724 & 801 & 794 \\
\hline Total & 3061 & 3017 & 3020 & 2995 & 2815 \\
\hline
\end{tabular}

Volumes of wood production decreased by $20 \%$ in the last two years because of the direct impact of the recession, very little in 2008 (less than by 1\%) and much more in $2009-19,7 \%$. It can be already stated that the economic recession had less impact on paper industry, while the share of wood production in the whole production industry decreased from $10.7 \%$ down to $10 \%$ in 2009.

Table 8. Rates of industry production (previous years 100\%).

\begin{tabular}{|l|c|c|c|c|c|}
\hline & $\mathbf{2 0 0 5}$ & $\mathbf{2 0 0 6}$ & $\mathbf{2 0 0 7}$ & $\mathbf{2 0 0 8}$ & $\mathbf{2 0 0 9}$ \\
\hline Whole industry & 107,0 & 106,5 & 102,4 & 105,5 & 85,4 \\
\hline Furniture & 115,0 & 105,5 & 108,3 & 89,8 & 79,4 \\
\hline Paper & 110,2 & 134,9 & 105,1 & 93,6 & 98,1 \\
\hline Timber & 111,3 & 130,7 & 115,7 & 111,6 & 77,6 \\
\hline
\end{tabular}

Lithuanian industry of wood products having experienced successful growth for many years in two recent years lost the production increase of the two previous years, two comparatively large furniture manufacturers went bankrupt: newly built Narbutas ir Ko in Ukmerge and Dilikas in Klaipeda, over ten smaller companies.

\section{Yearly wood production, million EUR}

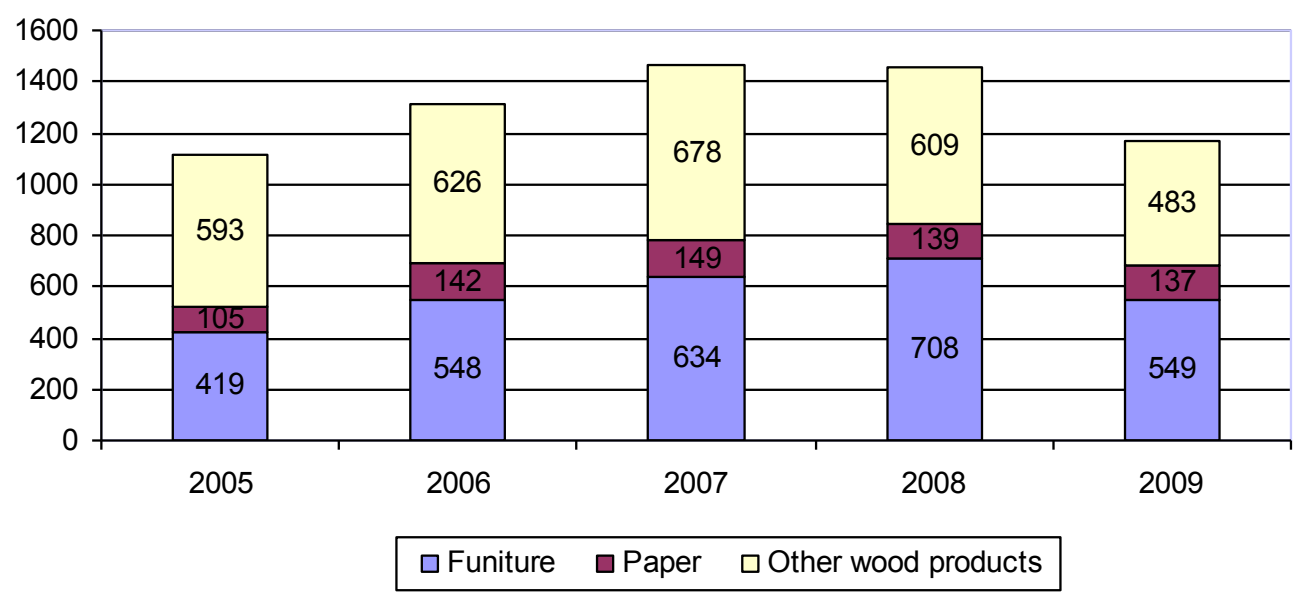

Figure 2. Yearly wood production, million EUR.

It is already evident that 2009 was not only the year of immense losses but also the year of production recovery. In the second half of the year production recovery trend was obvious.. 
The economic recession affected the distribution of wood production sale markets. In 2009, the share of products sold on the local market significantly decreased.

Table 9. Production volumes of the largest companies, million EUR

\begin{tabular}{|c|c|c|}
\hline Name & 2008 & 2009 \\
\hline 1. SWEDSPAN GIRIU BIZONAS & 71,9 & 61,2 \\
\hline 2. Klaipedos baldai & 53,7 & 48,9 \\
\hline 3. Klaipedos mediena & 41,8 & 44,5 \\
\hline 4. Boen Lietuva & 53,4 & 43,7 \\
\hline 5. Vilniaus baldai & 39,9 & 43,2 \\
\hline 6. Grigiskes Group & 42,0 & 34,2 \\
\hline 7. Visagino linija & 21,0 & 31,2 \\
\hline 8. Freda & 33,0 & 30,6 \\
\hline 9. Silutes baldai & 28,8 & 21,0 \\
\hline 10. Klaipedos kartonas & 31,2 & 18,3 \\
\hline 11. Stora Enso Timber & 17,3 & 17,1 \\
\hline 12. Sakuona & 10,3 & 13,4 \\
\hline Total 12 companies & 2500 & 407,3 \\
\hline Total wood industries & 1630,0 & 1256,0 \\
\hline 10 largest $\%$ & 27,3 & 32,4 \\
\hline
\end{tabular}

It can also be started that the economic recession had stronger effect on small businesses. This statement is confirmed by the dynamics of the share of companies' products.

In 2009 , it increased from $27.3 \%$ up to $32.4 \%$. Products of the whole wood industry estimated at the current year's prices decreased by $23 \%$ in 2009 , while of twelve largest companies only by $8.3 \%$. Production concentration is still ongoing.

\section{Table 10. Main wood products}

\begin{tabular}{|l|c|c|c|c|}
\hline Name & $\mathbf{2 0 0 6}$ & $\mathbf{2 0 0 7}$ & $\mathbf{2 0 0 8}$ & $\mathbf{2 0 0 9}$ \\
\hline Sawn timber, $1000 \mathrm{~m}^{3}$ & 1466,0 & 1378,0 & 1109,0 & 900,0 \\
\hline Wood chipboards, $1000 \mathrm{~m}^{3}$ & 285,7 & 437,8 & 515,4 & 473,2 \\
\hline Wood fiberboard, million $\mathrm{m}^{2}$ & 22,1 & 23,4 & 17,9 & 16,0 \\
\hline Plywood, $1000 \mathrm{~m}^{3}$ & 16,9 & 21,6 & 17,8 & 18,0 \\
\hline Windows, thousand & 153,9 & 195,3 & 170,8 & 119,2 \\
\hline Doors, thousand & 131,3 & 551,1 & 668,2 & 399,3 \\
\hline Paper and cardboard, thousand t & 119,2 & 139,8 & 122,7 & 86,4 \\
\hline $\begin{array}{l}\text { Corrugated cardboard and boxes, } \\
\text { thousand t }\end{array}$ & 65,1 & 70,3 & 61,9 & 55,6 \\
\hline
\end{tabular}

Four out of eleven largest companies (Visagino linija, Klaipedos mediena, Vilniaus baldai, and Sakuona) evaded the recession, continued increasing their production, while the worst effect of the recession was incurred by Klaipedos kartonas. The beginning of the year was very unsuccessful for latter company, because of the shortage of raw materials (waste paper), the company was forced to reduce its production volumes, to dismiss one third of this staff, to organize waste paper import from Russian and Belarus. By the end of the year Klaipedos kartonas resumed its regular operation but was not able to compensate its lagging in the past. Production volumes of six manufacturing companies controlled by SBA Group (Visagino linija, Klaipedos baldai, Silutes baldai, Kauno baldai, Germanika, and Novo Mebel) decreased by only $4.1 \%$ and nearly all production $(99 \%)$ was sold to IKEA Corporation in 2009 . The companies of this Group manufacture veneered cabinet furniture, tables and employ only half 
of their resources available into the production. This year, more orders from the Swedish IKEA are expected which would make the Group the biggest furniture supplier for this corporation in Europe.

\section{FOREIGN TRADE}

Export of Lithuanian wood products was increasing for a number of years and reached EUR 1.4 billion in 2007. Import experienced similar growth and reached EUR 900 million in the same year. The share of wood products in the whole export in 2007 accounted for $11.9 \%$, in 2009 it dropped down to $10.3 \%$. Foreign trade balance of wood products, differently from majority of other commodities, has always been positive. In the last two years, the total turnover of foreign trade in timber significantly decreased: export by $16.3 \%$, import by as many as $31.3 \%$. But in the second half of 2009 , the export recovered and demonstrated a good growth trend again.

Table 11. Largest exporters of wood products, million EUR

\begin{tabular}{|l|c|c|c|}
\hline & $\mathbf{2 0 0 7}$ & $\mathbf{2 0 0 8}$ & $\mathbf{2 0 0 9}$ \\
\hline 1. Klaipedos baldai & 44,0 & 53,3 & 48,3 \\
\hline 2. Vilniaus baldai & 42,8 & 39,4 & 43,0 \\
\hline 3. Swedspan Giriu bizonas & 50,2 & 48,4 & 40,3 \\
\hline 4. Boen Lietuva & 50,2 & 48,4 & 40,3 \\
\hline 5. Klaipedos mediena & 27,4 & 34,0 & 40,0 \\
\hline 6. Freda & 30,6 & 37,8 & 29,1 \\
\hline 7. Silutes baldai & 25,8 & 24,8 & 19,4 \\
\hline 8. Grigiskes & 12,6 & 16,4 & 17,1 \\
\hline 9. Sakuona & 11,2 & 9,9 & 13,2 \\
\hline 10. Klaipedos kartonas & 25,3 & 21,3 & 12,3 \\
\hline
\end{tabular}

The export recovery overtook production recovery speed. It shows that the wood producing industry has not lost its export markets yet. At the same time favorable changes in the export commodity structure should also be mentioned. In the last three years, the share of furniture in in the wood product export increased from $47 \%$ up to $54 \%$. The other same significant and favorable indicator is quite good export geography. In 2009, furniture manufactured in Lithuania was exported to forty countries in the world which at that time were either hardly affected by the economic recession or already recovered from it, as well as to the countries manufacturing big volumes of those products [7] It shows competitiveness of Lithuanian furniture. Great majority of furniture is now manufactured and exported by well-equipped large companies hardly affected by the economic recession. Therefore, furniture will probably be the backbone of the recovery and further development of the entire wood industry. 
Linnaeus ECO-TECH '10

Kalmar, Sweden, November 22-24, 2010

Furniture export geography in 2009, \%

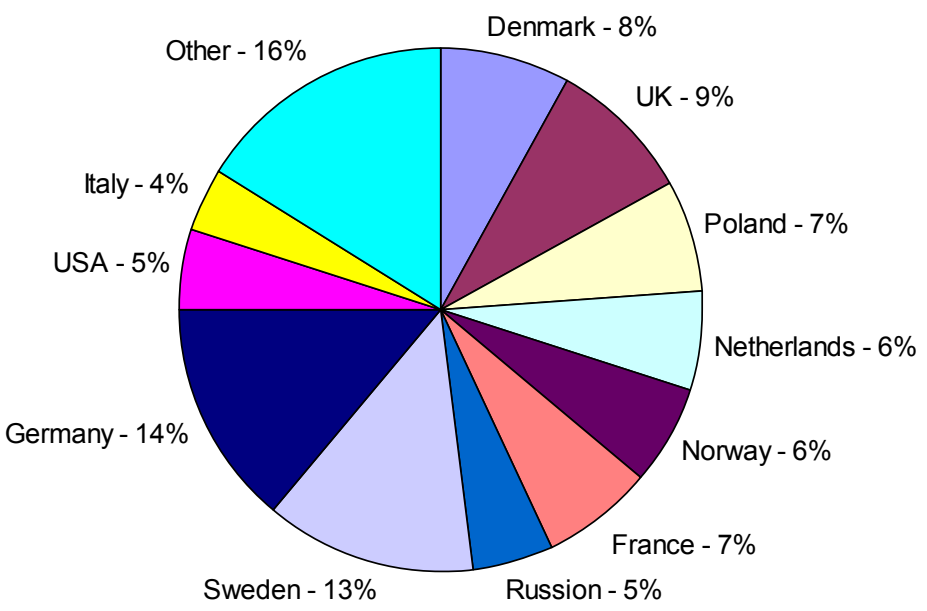

Figure 3. Furniture export geography in 2009, \%.

Table 12. Wood export goods

\begin{tabular}{|l|c|c|c|c|}
\hline \multirow{2}{*}{} & \multicolumn{2}{|c|}{$\mathbf{2 0 0 7}$} & \multicolumn{2}{c|}{$\mathbf{2 0 0 8}$} \\
\cline { 2 - 4 } & EUR, mln. & $\%$ & EUR, mln. & $\%$ \\
\hline 1. Furniture and its components & 646,4 & 45,4 & 651,8 & 48,6 \\
\hline 2. Paper & 145,0 & 10,2 & 152,6 & 11,3 \\
\hline 3. Joinery & 98,1 & 6,9 & 104,1 & 7,8 \\
\hline 4. Sawn wood & 141,4 & 9,9 & 91,3 & 6,8 \\
\hline 5. Round wood & 108,4 & 7,6 & 70,8 & 5,3 \\
\hline 6. Wooden packing & 68,4 & 4,8 & 65,6 & 4,9 \\
\hline 7. Wooden structures & 76,2 & 5,4 & 58,2 & 4,3 \\
\hline 8. Other wooden products & 138,3 & 9,8 & 147,0 & 11,0 \\
\hline
\end{tabular}


Table 13. Wood export goods

\begin{tabular}{|l|c|c|c|c|}
\hline \multirow{2}{*}{ Goods } & \multicolumn{2}{|c|}{$\mathbf{2 0 0 7}$} & \multicolumn{2}{c|}{$\mathbf{2 0 0 8}$} \\
\cline { 2 - 5 } & EUR, mln. & $\%$ & EUR, mln. & $\%$ \\
\hline Paper and its products & 313,8 & 36,6 & 333,3 & 40,3 \\
\hline Furniture & 163,7 & 19,1 & 165,1 & 20,0 \\
\hline Sawn wood & 106,6 & 12,4 & 73,6 & 8,9 \\
\hline Particle board & 75,6 & 8,8 & 67,6 & 8,2 \\
\hline Fiberboard & 37,1 & 4,3 & 37,0 & 4,5 \\
\hline Round wood & 20,3 & 2,4 & 10,2 & 1,2 \\
\hline Other goods & 140,6 & 16,4 & 140,0 & 16,9 \\
\hline
\end{tabular}

Paper and paper products have occupied the leading position among the wood import products for a number of years by now. The share of these products continues growing (2007 $-36.6 \%, 2008-40.3 \%, 2009-48.4 \%$ ). The share of the import of furniture, round and sawn wood is decreasing accordingly. That also represents favorable changes.

\section{LITHUANIAN FORESTRY GDP}

Forestry of Lithuania's GDP is low. It accounted for $0.43 \%$ of the country's GDP, in 2008. There is a forest GDP growth trend. From 1995 till 2008, Lithuanian GDP active forestry prices rose two-fold (Table 1). These changes resulted in forest products (round wood, etc.) volume and structure of prices. The largest factor was a round timber prices. In 1995, the average price of round wood was $75.6 \mathrm{Lt} / \mathrm{m}^{3}$, in $2008-134.0 \mathrm{Lt} / \mathrm{m}^{3}$.

Table 14. Lithuanian forestry GDP and labor productivity in 1995-2008

\begin{tabular}{|c|c|c|c|}
\hline Year & Forestry GDP, mln. Lt & Forestry workers, thousands & $\begin{array}{c}\text { Labour productivity, } \\
\text { thous. Lt/ employee }\end{array}$ \\
\hline 1995 & 233,8 & 16,1 & 14,5 \\
\hline 1996 & 234,3 & 15,9 & 14,7 \\
\hline 1997 & 237,1 & 15,0 & 15,8 \\
\hline 1998 & 242,8 & 13,7 & 17,7 \\
\hline 1999 & 200,4 & 11,5 & 17,4 \\
\hline 2000 & 246,5 & 11,4 & 21,6 \\
\hline 2001 & 248,1 & 10,6 & 23,4 \\
\hline 2002 & 263,6 & 9,9 & 26,6 \\
\hline 2003 & 284,3 & 9,7 & 29,3 \\
\hline 2004 & 311,7 & 9,7 & 32,1 \\
\hline 2005 & 342,5 & 10,3 & 33,3 \\
\hline 2006 & 384,6 & 9,5 & 40,5 \\
\hline 2007 & 519,6 & 9,6 & 54,1 \\
\hline 2008 & 477,4 & 9,6 & 49,7 \\
\hline
\end{tabular}

The most generalized productivity index is of added value (GDP) per worker. Increasing GDP and a decrease in the number of employees is a tendency to increase labor productivity. This increase would be lower due to incomplete accounting employed in forestry, especially in private forest owners, engaged in business activities, but outside the record.

WASTE AND WASTERWATER OF WOOD MANUFACTURING AND FURNITURE INDUSTRY 
Wood processing industry, product manufacturing process creates a lot of waste. Some are harmless, others - hazardous, the latter must be given special attention. Wood processing and furniture making produce waste that is often thrown away like trash, but should not be because of its hazardous nature. Hazardous waste - a toxic, flammable, explosive and other harmful substances that may harm human or animal health or the environment. Hazardous waste cannot be safety disposed without taking into account procedures for protecting the environment.

Wood waste categories, depending on the contamination:

1. Solid wood waste, or treated only mechanically, which use was slightly contaminated with substances harmful to wood;

2. Wood waste that has been glued, varnished, laminated or treated with paint, free halogen organic components and wood preservatives;

3. wood wastes, which are treated with paint containing halogen organic components, in addition to wood preservatives;

4. Waste wood treated with preservatives, such ties, poles and other wood waste;

5. Vehicle wash water, vehicle maintenance waste, air compressors, boilers and condensate waste, cleaning wastewater and other wastewater.

Furniture making requires the use of wood preservatives and coating materials all of which contain solvents. Both preservatives and coating material can generate contaminated wastewater as a result of: the drippage from the wood surface; leakage from the drums that store these chemicals; and the discard of used formulations. In the long run, contaminated wastewater can increase the concentration of toxics in the water supply to levels that are harmful to health and the productivity of operations. This may require wood processing operations to pay for procuring clean water or clean and recycle the water on-site.

Non-hazardous waste timber can be and are used for processing into other products for energy production. Currently, more than half of the district heat produced from biomass comes from sawmill waste. Lithuania dominant suppliers of wood waste during the past decade and is still in sawmills, wood processing companies. These other companies selling consumer wood waste technology waste products. Currently, more than half of the centrally produced biomass heat comes from sawmill waste.

Decontamination of hazardous chemical waste is a problem all over the world, including Lithuania. The world currently uses various methods of treating such materials, according to the nature of the wastes: oxidation, neutralization, incineration, biodegradability, partial or complete recovery of chemical components and the like. Lithuania hazardous waste storage started on their conditions improves. For this purpose, it was established a specialized UAB Toksika and its regional branches in Siauliai, Klaipeda and Alytus. Click here to hazardous chemical waste collected from their owners, storage and possibly recovered. Waste storage UAB Toksika and its subsidiaries are met. It is also satisfactory in most cases can be considered which are regarded as chemical waste to the manufacturers - offices and companies, where they occur. However, in some cases, a precise knowledge of hazardous chemicals is not known [8].

Most of the industrial wastewater discharged into Lithuania and sewerage networks, before being released into surface waters, treated urban waste water treatment plants. Accordingly, the industrial wastewater and sewage networks, it is necessary to take into account the specific water pollution. 
The surface water was released in 2008 about 175 million. $\mathrm{m}^{3}$ purified municipal and industrial wastewater - about 7 percent. Less than 2007 In 2008, cleaned up to standards, inadequately treated and untreated sewage released ratio of the total runoff volume was respectively $72.4,27.3$ and 0.3 percent [3].

Lithuania from the timber industry issued industrial wastewater flows data is not available.

Lithuania generated hazardous wastes and hazardous waste collection and disposal by the Environmental Protection Agency. This agency's mission - to collect, analyze and provide reliable information on the natural environment, the flow of chemicals and pollution prevention tools, providing adequate environmental protection and state control of environmental regulation and oversight to ensure water conservation and water protection management organization achieve its objectives. In 2009, collected or accumulated waste in the timber industry to the Table 17.

According to the Environmental Protection Agency, the wood products industry and its manufacturing processes at the beginning of 2009 was raised to 42,797 tons of various industrial wood waste. 2009 year-end balance of wood industry waste was 43,089 tones. Hazardous waste in early 2009 was 285 tons, and at the end of the year - 2,532 tons.

Waste management is the one of the priority areas in the protection of environment. This importance is pointed in the National Environment Protection Strategy, which was approved by the Government of Lithuania in 1996. The development of the waste management system was an important issue during the Lithuanian integration process into European Union. For this reason the National Strategic Waste Management Plan was prepared according to EU legal requirements in waste management area. All processes need to be supervised as they would otherwise lead to danger to the environment or resource depletion. In order to avoid negative impacts of the waste management sector on the environment.

\section{CONCLUSION}

- Timber Industry development in Lithuania is very favorable. Lithuanian woodland take about 2045 thousand ha of total Lithuania territory. In 2009, the state owned 1065 thousand ha or $49 \%$ of the forests. The other part consists of private forests and woodlands intended for privatization (restitution).

- In Lithuania, there are 2815 companies of various sizes, which were engaged in manufacturing of wood products. In 2009, there were 655 companies of forestry industry, 1274 of timber industry, 92 of paper industry and 794 of furniture industry. It shows, that Lithuanian industry of wood products having experienced successful growth for many years.

- In 2009, there were produced products of furniture industry for about 549 million EUR, of paper industry for about 137 million EUR, and of other wood products for about 483 million EUR.

- In $2007-2009$, the share of furniture in the wood product export increased from $47 \%$ up to $54 \%$. The other same significant and favorable indicator is quite good export geography. In 2009, furniture manufacturing in Lithuania was exported to forty countries in the world.

- Lithuanian producers of wooden houses are successfully competing in foreign markets for several reasons. First of all, it because of deep - rooted traditions of wood homes and strong wood industry in Lithuania. Quite cheap labor force and high qualifications are big competitive advantages on foreign markets. Labor costs account for a fairly big share in the structure of cost price of log houses. In addition, local resources of high - quality wood are also big. With a view to extending to foreign markets, producers of wooden 
houses implement advanced technologies and innovations, develop new products and improve corporate specialization. This will serve as a basis for successful competing in global markets in future.

- The wood products industry and its manufacturing processes at the beginning of 2009 was raised to 42,797 tons of various industrial wood waste. 2009 year-end balance of wood industry waste was 43,089 tones. Hazardous waste in early 2009 was 285 tons, and at the end of the year - 2,532 tons. Wastewater flows data and its poluttion from the timber industry are not available.

\section{REFERENCES}

[1] A.Morkevicius (2010): Medienos sektorius $2010 \mathrm{~m}$ (The sector of timber ). 1 pusmetyje. http://www.lietuvosmediena.lt/sector2010I.pdf.

[2] A.Morkevicius (2010). Lithuanian Forest cluster. Lithuanian Forestry sector in 2010. http://www.lietuvosmediena.1t/LithuanianForestCluster.pdf

[3] A.Gaizutis, J. Kurtinaitiene (2007). Lithuanian forestry sector development opportunities: current competitive advantages and possible growth trends. ISSN 1392-1258. Ekonomika, 2007-79.

[4] Association of timber houses producers (2010): http:// www.timberhouses.lt/en.php?StructureId $=116$

[5] St.Mizaras (2010). Lietuvos miškų ūkio bandrasis vidaus produktas ir darbo našumas. „Miškų girios“, Nr. 2010/05. http://www.forest.lt/go.php/lit/St.Mizaras apie Lietuvos misku ukio_BVP /2926.

[6] A. Gaizutis. 2005. Gaining a position for small-scale private forestry trough creation of marketing system for wood trade: case of Lithuania. In S. Mizaras, ed. Small-scale forestry in a changing environment, p. 130-136. Proceedings of an international symposium, IUFRO Research Group 3.08.00, Vilnius, Lithuania, 30 May - 4 June 2005. Kaunas, Lithuania, Lithuanian Forest Research Institute.

[7] State Forest Survey Service of Lithuania. 2007. Private forest statistics. Kaunas, Lithuania, Ministry of Environment. Available online: www.lvmi.lt/vmt [In Lithuanian].

[8] R. Ragauskas, 2005. Susikaupusių ir naujai susidarančių pavojingų cheminių atliekų Lietuvoje srautai ir jų galutinio nukenksminimo galimybiu studija, (New and dangerous chemical waste arising from Lithuania flows and their final feasibility study).

[9] Aplinkos apsaugos agentūra, 2010. (Environmental Protections agency): < http://gamta.lt/>.

[10] Lithuanian EPA, 2009. The state of the environment 2008, Vilnius: $\langle$ http://www.am.lt $>$. 
Linnaeus ECO-TECH '10

Kalmar, Sweden, November 22-24, 2010

Table 17. Wood waste in timber industry, 2009 [10].

\begin{tabular}{|c|c|c|c|c|c|c|c|c|c|c|c|}
\hline \multirow[b]{3}{*}{ Title } & \multirow{3}{*}{$\begin{array}{l}\text { Amount at the } \\
\text { beginning of the } \\
\text { year, ton }\end{array}$} & \multirow{3}{*}{$\begin{array}{l}\text { Composed/ } \\
\text { collected } \\
\text { amount, ton }\end{array}$} & \multicolumn{8}{|c|}{ Processed, ton } & \multirow{3}{*}{$\begin{array}{l}\text { Amount at the } \\
\text { end of the year, } \\
\text { ton }\end{array}$} \\
\hline & & & \multicolumn{2}{|c|}{ Elimination } & \multirow[t]{2}{*}{ Export } & \multicolumn{2}{|c|}{ Burning } & \multirow[b]{2}{*}{ Adaptation } & \multirow[b]{2}{*}{$\begin{array}{c}\text { Other } \\
\text { consumption }\end{array}$} & \multirow[b]{2}{*}{ Treatment } & \\
\hline & & & In dump & $\begin{array}{l}\text { Other } \\
\text { methods }\end{array}$ & & $\begin{array}{c}\text { For energy } \\
\text { production/ } \\
\text { fuel }\end{array}$ & $\begin{array}{c}\text { In } \\
\text { overland }\end{array}$ & & & & \\
\hline \multicolumn{12}{|l|}{ Inoffensive waste } \\
\hline forestry waste & 6411,627 & 32040,784 & 8019,127 & 0,000 & 0,000 & 49,000 & 0,000 & 22212,038 & 1119,000 & 0,000 & 7053,246 \\
\hline bark and wood waste & 892,850 & 7652,401 & 0,000 & 0,000 & 0,000 & 6105,201 & 0,000 & 1289,600 & 117,000 & 0,000 & 1033,450 \\
\hline sawdust and shavings & 25623,405 & 178466,050 & 3889,110 & 0,000 & 0,000 & 110770,322 & 0,000 & 64945,430 & 3499,868 & 0,000 & 20984,725 \\
\hline $\begin{array}{l}\text { mechanically } \\
\text { separated paper and } \\
\text { cardboard waste } \\
\text { rejects from pulping }\end{array}$ & 0,000 & 0,000 & 0,000 & 0,000 & 0,000 & 0,000 & 0,000 & 0,000 & 0,000 & 0,000 & 0,000 \\
\hline $\begin{array}{lr}\text { recycling paper and } \\
\text { cardboard } \\
\text { sorting }\end{array}$ & 31,762 & 2900,876 & 0,000 & 0,000 & 845,835 & 0,000 & 0,000 & 0,000 & 0,000 & 0,000 & 2086,803 \\
\hline $\begin{array}{l}\text { paper and cardboard } \\
\text { packaging }\end{array}$ & 3937,709 & 59898,046 & 0,000 & 0,000 & 19536,201 & 7,690 & 0,000 & 40750,990 & 0,000 & 0,000 & 3540,874 \\
\hline wooden packaging & 595,113 & 19676,964 & 0,000 & 0,000 & 0,000 & 1866,003 & 0,000 & 17596,687 & 77,200 & 0,000 & 732,187 \\
\hline wood & 1828,613 & 1762,515 & 464,660 & 0,000 & 0,000 & 105,400 & 2,830 & 1691,030 & 0,000 & 0,000 & 1327,208 \\
\hline paper and paperboard & 3097,249 & 30643,609 & 45,789 & 0,000 & 10914,515 & 42,943 & 0,000 & 18835,228 & 150,742 & 0,000 & 3751,641 \\
\hline other wood waste & 93,217 & 1286,281 & 728,090 & 0,000 & 0,000 & 155,231 & 0,000 & 406,580 & 43,117 & 0,000 & 46,480 \\
\hline \multicolumn{12}{|l|}{ Hazardous waste } \\
\hline bark and wood waste & 265,900 & 5480,725 & 39,740 & 0,000 & 0,000 & 3103,380 & 0,000 & 92,470 & 0,000 & 0,000 & 2511,035 \\
\hline sawdust and shavings & 0,038 & 0,336 & 0,000 & 0,000 & 0,000 & 0,000 & 0,000 & 0,000 & 0,000 & 0,000 & 0,374 \\
\hline other wood waste & 19,231 & 1,315 & 0,000 & 0,000 & 0,000 & 0,000 & 0,000 & 0,000 & 0,000 & 0,000 & 20,546 \\
\hline
\end{tabular}

